\title{
Performing Cities: Engaging the High-Tech Flâneur
}

Karen Rodríguez

CIEE, Guanajuato, Mexico

\section{Bradley Rink}

CIEE, Stellenbosch, South Africa

\section{Students and the City}

The city as place forms the backdrop to many study abroad experiences. Our sense of place, however, is often fractured by modern mobilities. As Sack (1988) notes, we move from place to place so much that places often begin to appear ever more generic and alike. Or they seem to be "out there," and we forget that they are humanly constructed. If we now have trouble conceptualizing place, when we turn to cities in particular, we also find that they are being submerged into a discourse of sameness where today's "global cities" are portrayed as almost cookie-cutter copies of one another in their consumption-based, high tech identities. Yet the culture-neutral character of this discourse about contemporary cities belies the cultural-historical personality that each city retains, and it can obscure or even erase the rich placespecific learning opportunities that each city offers.

As international educators, the overwhelmingly urban context of study abroad requires not only a more intense querying of "the city" as a concept, but also more attention to how students could engage with and learn from the urban landscape. In this article, we begin with a theoretical flânerie through a range of ideas related to the city in order to frame programmatic strategies for promoting a more critical student engagement with urban spaces and places. We ask:

- How does the student become an observer and self-conscious performer of the urban landscape?

- How does the city observe and perform back?

- How can we move students toward the sort of intimate, local knowledge cultivated by Baudelaire's 19th century flâneur? 
We pay particular attention to the fact that students now come into study abroad cities armed with a battery of technological tools, unlike their 19 th century counterpart. We question whether students, our now technoflâneurs, are employing these tools to engage with the spaces and places of locality or simply creating endless images and representations about these abroad cities without any real thought or connection. We aim to provoke thought about how we might profitably harness the possibilities of students' new media use toward our pedagogical ends.

We therefore cover both theoretical and practical matters to encourage practitioners to infuse programming with increased local specificity as we welcome the current generation of study abroad participants into what is still a plethora of urban difference.

\section{Theoretical Framing: of Places and Cities}

Regardless of the type of education abroad experience that we offer, the currency of the international educator is ultimately that of place. We promote the difference of places around the world and rely on this uniqueness to enable and to enhance the student learning experience. Our efforts are based on the understanding that sending a student to study in a different place will serve as the catalyst to new learning opportunities now that that student has been displaced from his/her normal environment. Thus, place matters in education abroad. But place is complex, as Knopp (2007) notes:

[Places] are constituted by ever-changing practices and purposes that are both informed by and generative of all kinds of lingering legacies...many of these legacies are themselves products of the interactions between human beings, their material and semiotic creations, and nonhuman forces, in complex networks and relationships (such as those embodied in technologies, institutions, and infrastructures. (Knopp, 2007, p. 50)

In short, place acts as a "centre of action and intention" (Relph, 1976, p. 42), much like an environment for engaged learning. From place-related literature emerges a first set of concerns: We hope for our students to question not only how local residents act and what they intend, but also how the city itself acts and what the city might intend in response, all the while considering their own actions and intentions with regard to place. We also aim for students to under- 
stand how locals interact with language, urban sites, insiders and outsiders, and how this all comes together to somehow create the elusive "sense of place" they should be trying to articulate during and after a study abroad experience.

In the literature, some works assert that individual cities have lost their footing as the global seems more prominent. French scholar Jacques Attali, for example, argues that new travelers "may not thrill to Baudelaire's 'shock' of the metropolis, but to the 'sonic boom' of the global world" (cited in Mazlich, 1994, p. 56). Other scholars have also pushed our gaze toward the blanket global city (Smith, 2003); however, these descriptions, while apt on one level, often leave out the very real historical and cultural specificity (Cape Town and its former regime of racialized spatial control) and ignore such obvious factors as the different sizes of urban locales (Guanajuato as a small city, and the rather staggering absence of attention to the case of small cities enmeshed in global processes, Bell and Jayne, 2006). Despite some shared experiences of global goods and the equally important circulation of ideas, cities have specific histories and characteristics that still impinge on everyday life.

With respect to everyday life, Mexico City anthropologist Néstor García Canclini (1995) maintains:

The meaning of the city is constituted by what the city gives and what it does not give, by what the subjects can do with their lives in the middle of the factors that determine their habitat, and by what they imagine about themselves and about others in order to "suture" the flaws, the absences, and the disappointments with which the urban structures and interactions respond to their needs and desires. (p. 751)

From here, we derive another key set of questions: How do study abroad students enter in a city's process of subjectivity construction? Do they feed into what the city wants, or do they disrupt it? Can students think about what their presence allows a city to do, to be, to communicate? Can they learn to perceive "...the often incommunicable relationship between a city and its inhabitants"? (Coverly, 2006, p. 25). If public space is both produced and constructed through everyday use, images, memory, etc. (Low, 1996), and its meanings are both multiple and contested, how do students contribute to these processes? Can they learn to read this city specificity which merges insiders' and outsiders' multiple affective and physical engagements with urban space? This takes us to the notion of the flâneur and work on urban engagement. 


\section{The Problem: from Turtles to Text-Messaging}

The term flâneur emerged in the work of French poet Charles Baudelaire in the late 19th century, most notably in his 1863 essay, "The Painter of Modern Life" and in his iconic poem, "A une passante" in Les Fleurs du Mal (1857). The notion was later expanded in Walter Benjamin's The Arcades Project, and has been discussed most recently by a range of cultural studies scholars (Jenks and Neves, 2000; Tester, 1994; Parsons, 2000). The flâneur as urban figure is linked to the advent of modernity — indeed he is somewhat of an archetypal character representing the privileged response (an enjoyment of and access to public spaces, including the consumerized spaces of the shopping arcade) to the rapid urbanization taking place in 19th century Europe. He is a fritterer of time, a shopper, a show-goer... yet he is somewhat intellectual; he is taking notes. He is a "'botanist of the sidewalk' who wants to become one flesh with the crowd" (Baudelaire, 1964, p. 9), and he prefigures the modern tourist. At his heyday, the flâneur strolled leisurely through Paris' changing urban landscape with a turtle on a leash to force himself to slow down and take it all in.

As an urban dandy, observer, and mover through space, the flâneur also inscribes the space, engaging in active spectatorship and creating texts about the city. De Certeau (1974) refers to the textual-spatial strategy of engaging with the city when he identifies walking as an act of enunciation, like a speech act (1974, p. 98). Understanding the flâneur's strolling in this way, one understands the possibilities for dialogue with the city rather than simply talking to oneself. Although he may be a solitary figure, the flâneur is giving and taking from his urban playground, and the conversation may be filled with emotions, memories and a very distinct sense of place, all of which position the city as co-subject in his constructions of representations.

One is also led back to psychogeography as posited by Guy Debord (1967) and others. Psychogeography is specifically concerned with the psychological impact or effects of space on its inhabitants. Its roots can be traced to the Situationist dérive (a sort of affective drift through space), although it regained force in the 1990s in the UK in particular (Coverly, 2006; Pile, 2005). By walking and mapping personal tracks across the city, psychogeographers argue that alternative (more playful or more critical) maps can be made, which open up new views of the same spaces. Both 
historically and currently, therefore, psychogeography has come to be associated with social movements, street theatre and protest (Pinder, 2005). Pinder highlights the importance of psychogeography and the city when he suggests that:

...if psychogeographical explorations retain associations of the marginal and even illicit,, their significance for developing critical understandings of cities has been increasingly recognized. (2005, p. 389)

These figures and models for urban engagement are highly relevant, both in the contemporary context and in the case of the study abroad urban explorer. We argue that there can be resistant and alternative models for students' walking through the city. However, in order to tease out the creative and critical learning possibilities afforded by these models, it is first necessary to consider the specific nature of our student flâneur.

\section{The Student Wanderer - Equipped with Technology}

If walking is akin to a speech act, this has never been more true as the student-walker texts, tapes, e-mails, blogs, photographs and films their explorations of the study abroad site. Indeed, the wiki-lifestyle that characterizes the current generation of study abroad students (participation in virtual text creation of myriad types and often in fragmented form) is one characterized by constant connection and accompaniment by technology. Given the degree to which students maintain their connections with the world beyond their immediate setting of their study abroad location, it is clear that the study abroad experience is highly moderated by the use and reliance on information and communications technology (ICT). Technology is a constant companion (in the form of cell phones, smart phones, MP3 players, digital still cameras, and digital video camera) and thus acts to moderate students' experience of the city, setting expectations and creating fixed itineraries and ways of understanding the urban landscape. In the global South (countries that are often referred to as developing or Third World), it is important to note that these itineraries tend to favor the formal aspects of the city over the informal (which matters), and are therefore often heavily informed by race, class, and tourist desires, as cities strive to present certain images of self and hide others. Certainly, a shake of the 
iPhone will pull up a predictably skewed representation of a site, just as Googling $^{\mathrm{Ta}}$ neighborhoods and names would provide a revealing look at who is represented virtually, and who is not.

When a student navigates through the city not by wandering but by Googling $^{\text {Tw }}$ the most efficient route between two points, their experience has been mediated by technology. When step-by-step instruction-and not emotion-is the compass that guides them, their understanding of the city is mediated by technology. When fear of an informal neighborhood eschewed by modern, geo-referenced mapping drives their pedestrian itinerary, then they have been mediated by technology. When the desire to explore remote corners is precipitated by blogs of those who came before instead of etching a personal cartography of their experience, they have been mediated by technology. When their gaze remains fixed on their phones and never meets a local person's eyes, they have been mediated (or perhaps dominated!) by technology. While the genius of satellite navigation and geo-referenced databases serve as invaluable wayfinders to the weary motorist, such technologies omit many people and their lives from our collective cartographic memory.

As such, technology, like maps themselves, cannot tell the whole story and cannot supply the infinite ways of seeing and feeling the city. As Stephen Hall (2004) notes,

What the map fails to supply, the human mind (or human yearning) sometimes has the power to conjure. It seems somehow easier to conjure up possibility out of a map than out of the sheer ether; perhaps we imagine the coordinates of latitude and longitude as a safety net. $(2004$, p. 16)

In the case of the current generation of study abroad students, the metaphorical net of longitude and latitude can also be seen in the virtual net of connectivity through hand-held computer technology. The connection that such technologies enable serve students' need for information, while providing a false sense of security that immediate contact with familiar social and communicative networks may give them. Just as early explorers may have feared going "off the map" into the realm of fantastic sea monsters, current students may avoid that which is not searchable, mappable and understood through the use of technology. This relationship between students and technology is driven by demands of the millennial generation, by the accessibility of high-tech gadgetry, and the degree to which such technology has 
become an integral part of students' social lives. In this way, technology acts as a method of communicating with the world, while also a mediator of one's connection to it.

Baudelaire lambasted the arrival of the camera, the high tech gadget of his day, and he would most likely be appalled by how much technology our student-flâneurs employ in their study abroad cities! As educators, we are certainly not anti-technology, but like Baudelaire, we too have concerns. The idea of losing oneself in the crowd like the Parisian flâneur is wonderful, but given the technology issue, one might ask into which crowd are students merging? The local or the virtual? The disembodied nature of their experience is worrisome indeed, and we might also question what language is being used in their high-speed, multimedia communications and who their audiences are... Similarly, while we recognize that technology has great potential to help students slow down, pay attention, and respond to the barrage of images with their own critical interventions, we also worry that technology could be providing a strategy for avoiding engagement. How to make sure technology is not a refuge but a means; a connection to the local rather than that which is distant? How might students engage in critical strolling, loitering, and a sort of exploration that is at once informed but not over-prescribed, over-mediated? How can students not only pose critical questions about place, but also hear what a city says in return?

\section{The Model:}

\section{a View of the Student FIâneur}

We envision a student flâneur enacting Guy Debord's dérive (1994), but equipped with a new way of walking, seeing and participating in the city, and who can now engage with the unlimited learning potential that the urban environment holds (Perkins 2007, p. 128). Our vision of the student flâneur is also one where technology is present, but where it serves not to mediate the experience, but rather to enhance the student's connection to "the local." We offer three assertions:

First, the student should be understood as simultaneously spectator, wanderer, and performer. Students are spectators - they are in a new city precisely to pay attention, and they may step back to look as they search for words, search for online information, or simply try to take in the urban landscape. They experience the spectacle of the city through its vis- 
ible culture of arts, social movements, and street life (Pinder 2005), and this forms the basis of their understanding of the difference of place. Yet as they spectate, students also wander through the urban locale; they are not stationary observers, and sometimes they move through both city space and virtual space at once. Their mobilities are both mundane and extraordinary, and their traverses through the city overlap and intersect with the everyday movements of local inhabitants, who are also frequently travelling through the real and the virtual at once. As observer-wanderers, students focus their gaze not only upon the actors in their new surroundings, but also on themselves as they work out tentative performances of an intercultural self.

These everyday and extraordinary wanderings thus establish students as performers. Students perform the city with a script moderated by their own identities, their emerging (and changing) understanding of the urban landscape, and the spontaneous/unscripted responses of local others, their co-performers. Therefore, the acts of spectating, wandering and performing should be conceived of as fluid and concurrent. This undoes the binary constructions of observer/actor, being reflective/active, thinking about self/ thinking about other, and it allows students to wander in a more complex state of engagement with their urban surroundings.

An illustration of this can be found in the common example of students' presence alongside street children (whether in the South African or Mexican context), a presence which immediately changes (and charges) the urban dynamic. As the wandering of student intersects the wandering of the child, both participants are temporarily disrupted by the resulting performance between them. The interaction precipitates a negotiation of identities where the presumptions of wealthy foreigner and disadvantaged child set the stage for a negotiated economic transaction. Will the child ask for money? Should the student be cautious or altruistic? Or are two worlds simply colliding on the urban stage with the result resting in the subjectivity of the two actors involved?

The scene is fluid and may be influenced by a multitude of urban factors that complication the negotiation in progress. This same negotiation takes place in the indoor and/or private spaces of urban life as well, for example at family birthday parties, where the family expands to people not used to interacting with foreign students, or in churches not of students' religions, and so on. These very unspectacular, everyday examples illustrate how students enact this multiple set of roles in the urban setting, and how they 
might shift from wandering through an urban space, to observing children, to performing a role in response to the economic need or affective pull that the children exert on them, whether they see the role as generous outsider, guilty privileged person, empathic (temporary) co-resident... These minor meanderings become complex, indeed.

For along with our students, those from the host culture are concurrently observing urban life, wandering through city space, and performing for a range of audiences. The street children might likely adjust their performances to the student-public (in parts of Mexico, they employ the native language to these ends; in others they throw out words of English). Others on the street (vendors, would-be suitors, local students...) also enact performances highly related to our students' ethnicity, national identity, gender, and other factors. Both students and locals can thus be seen as situated on the "edges" because of a host of observable factors that give clues about their national identities; their linguistic and social status; and their (perceived) economic status. They find themselves in unstable subjectivity positions that must be multiply performed, negotiated, and ultimately (re)resolved within the urban contact zone (à la Mary Louise Pratt, 1999) where they meet time and over again.

We therefore also underline, secondly, that the city itself is observing and performing back. The city is not the stage upon which the student performs, nor the passive backdrop through which the flâneur strolls. Rather, cities, like human subjects, are always in a state of becoming, in crisis, and struggling to maintain their subjectivity. Because they are multiply constructed, and each construction depends upon what sort of engagement underlies the construction, Goh and Yeo assert that "city sites are indeed aporetic, if the totality of these competing significations are taken into account" (2001, p. 6). In response to the need to create a viable subjectivity, cities will exclude some people/styles/ ideas in an attempt to achieve their own ideal of a perfect city. And they will have to work through a range of people/styles/ideas to decide which are more "self," which are more "other," and how to manage them into the spaces and places at hand. Having students think through how some others enhance the city's identity while other others are used as foil to display what the city thinks it is NOT opens up an interesting discussion as well. These differences are deeply rooted in the historical, cultural, and economic experiences of the urban locale; and beyond a doubt, if a student were to be able to articulate and explain these differences, she would have achieved a critical "sense of place." 
And third, technology is a crucial mediator. We have already discussed students' use of technology. Accepting that technology-and the media it connects to, and the representations it permits-will inform any urban flânerie, it is our final assertion that technology acts as a crucial mediator in the education abroad student's experience of the city. While technology mediates student life on the home campus in the form of email communication, social networking, wayfinding and any number of consumptive pursuits, it is natural that students bring the technology and use it in similar ways while abroad. The challenge lies in moving from a functional and documentary use of technology to a more critical, analytical and even dialogic employment of it. But a re-conceptualization of the student techno-flâneur is not a literary endeavor in the study abroad context; it must afford strategies that promote both deep thinking and deep connecting with the site and its inhabitants. Therefore, we turn our attention next to thinking about how to promote this sort of "right wandering."

Conceived as such, students' right wandering among others involves a more critical seeing, walking, and participating on the shared city stage. To sharpen the spectating, we would be well-advised to have students engage with critical visual studies (and critical media studies) in order to have a new set of terms with which to articulate both how they gaze and what they are seeing, and how the visual element of a cityscape is necessarily intertextually constructed. Capturing new visions through new media use as students walk through and engage with spaces and their inhabitants can certainly be mobilized for critical intercultural learning. The final section takes on the question of how to put these ideas into practice.

\section{A More Critical Spectating, Wandering, and Performing: Putting Our Principles in Motion}

In order to put our techno-flâneur in motion, we advocate helping students construct and reflect about both alternative and collective cartographies.

\section{Alternative cartographies}

Alternative cartographies permit resistant, other views of the city; they keep learning open and unfinished - they allow a city to remain as elusive and changing as a person, who we can also engage deeply but never fully know. While there are infinite alternative cartographies one could invent 
and explore with students, we mention a few ideas as points of departure. First, we could encourage students to experiment with critical spatial shifts, which bring other sites of the city into view and highlight people or sites that were previously unseen. Spatial shifts allow us to embrace new ways of seeing who (and what) is where in the city, and they catalyze critical reflection about the non-neutral nature of our daily trajectories.

For example, students could be asked to trace the typical mobilities from a sample of working class Cape Town residents and then contrast these with the tourist routes of the city. What are their literal and figurative points of departure? Which routes of the city does each group ply, and which nodes do they traverse? In Guanajuato, students could ask how it is that in a city whose beauty comes from the silver mines, one rarely sees a miner above ground or in main plazas? Mapping such spatialities with students can illuminate the multitude of layers in the city and can open new possibilities for understanding issues of urban culture, social justice, economics and labor. These mappings can also be critically juxtaposed with existing urban texts such as tourist brochures, event notices, political signage, and cultural spectacles. What is being said in which city sites? And who is receiving which messages? These ideas can be further triangulated at the technological level - which sites and inhabitants can be Googled ${ }^{\mathrm{m}}$, and which cannot?

Pulling from psychogeography, students can be asked to drift purposefully through the city paying attention to how the affective and social climate shifts as one moves into different neighborhoods. Walking through the downtown area, at what point does the economic level change? Is there a racial shift as well? How can one feel this out, map it, visually or verbally? At what precise point does the ambiance take on a different feeling? How does well-heeled ease into unsafe? Where can women be or not be at certain times of the day or night, and how does space reproduce gender norms and hierarchies? How does sexuality get mapped? In Cape Town, the Pink Map attempts to cartographically represent all that is "pink" (read: queer) in the city (Rink 2008). How do these areas mesh with (or not) other mappings of the city? In Guanajuato, there is no such map, which says something quite different about this city and about how sexual subjectivities are visible or invisible - but nonetheless part of the urban landscape. Taking on such a mapping of sexuality would be highly resistant to mainstream representations about public space (the public face) of this city which tends to deny some of its private aspects (Rodríguez, 2009). 
Even mundane objects can be mapped, and we can learn a great deal from them: Cartographer Denis Wood, for example, mapped jack o'lanterns in Boylan Heights, North Carolina to underline a class distinction, as those without extra income do not invest in decorative pumpkins (Wood, 2004). One can easily think of the place-specific objects in other locales that could be critically mapped to illuminate similar sorts of things. Who puts up door-front altars in Holy Week? Where does one observe a given fashion trend, and where not? Where do we see US-style Christmas decorations, in neighborhoods with migrant ties or in high-end areas where people shop for imported signs of global hipness? How could representations of both be dialogued together?

Students can also be asked to examine how time interacts with space to produce a different cast of actors and genre of performances within a single space as day turns to night, or low tourist season turns to high. What does this say about what a city means and what it enacts? Students in Guanajuato will note that early morning on the main Jardín is dominated by society ladies, university leaders, and politicians, whereas at night, the same spot becomes a focal point of youth culture that is practically unfathomable at 9 a.m. Similar interrogations would reveal the appropriation of what may otherwise be considered useless space on the verge of a national highway in Cape Town for recreational purposes. As the school day ends or the weekend begins, a keen urban eye would note how these spaces are performed as something other than their original purpose. Patches of roadside grass, dirt and rubble become an outlet for the dreams of soccer superstars to-be, as township soccer clubs make use of an otherwise liminal space in reaction to the lack of such formalized spaces in the local context.

Mapping space can therefore be put into dialogue with a range of elements related to a city's own performances of subjectivity. What is mapped and what is not also provides new ways of understanding how discourses define and divide the city: herein a link to language learning as well, as students think about what literally can and cannot be expressed in the local language, what is and what is not spoken about, what is charted onto formal maps, and what is not. The pedagogical possibilities for critical reflection are infinite.

Another way to permit students to create alternative cartographies is to shift away from the ocularcentric toward more fully embodied itineraries. Our current approaches tend to favor the visual elements of the city; however we could certainly expand our strategies to include the other senses. 
Students could be encouraged to study city soundscapes as signs of the sustained individuality of place. In Guanajuato, for example, sounds are highly site-specific and can be mapped to show overall commonality as well as classdifferences; in other words, while some sounds affect everyone (barking dogs, church bells, the gas man, the water trucks with loudspeakers) which might suggest a certain democratic cacophony, other sounds (types of music, the various cries of vendors, and linguistic variation) also mark subtle class differences across this. Similarly, in Cape Town, the smells of curry spice and incense that emanate from the predominantly Muslim area of the city known as the Bo-Kaap, offer one example of a "scentscape" that delineates the ethnic and religious borders of the city. These are the sorts of things students often notice in passing (descriptively), but that could be fruitfully engaged for critical thinking about differences both between and within cities.

Not only could sounds be recorded and combined with visual data to create fuller maps; but smell and tactile experiences could be mapped and paired with the visual as well. Technology could thus serve to capture and create representations of this data, as students put new placemarkers on Google Earth"; or create local "green" or even "pink" maps from newly acquired data. These alternative maps of the unsaid, the unseen, the ephemeral, and the embodied not only serve the current generation's call for an open-source paradigm of participation, but they also function to challenge the mainstream, dominant representations distributed by institutions or sites of power.

\section{Collective cartographies}

The strategies mentioned above would diversify and deepen students' understandings of a city as they think through the effects they and the city exert on each other and explore different parts of the city in different ways/ through different perspectives. One must be careful, however, not to isolate (or reify) the student flâneur. It is equally crucial to consider where the individual urban experience overlaps with the collective experience of the city. How does a student's "My Guanajuato" or "My Cape Town" relate to the local experience, or everyone's co-mingled daily life, in places whose identities depend at least in part on these self-meets-other nuances in the first place? And what collaborative possibilities exist here for creating new technology-aided mappings? 
One suggestion for practice might include asking students to create maps of the social networks they have formed-as posited by sociologist Charles Tilly (2005) in which they document their social connections within the city - who they first met, how they met more people, where these meetings took place and where relationships played out, how one connection led to another, and so on. This sort of mapping shifts the view from me-in-a-space to wetogether-in-a-place informed by affective and social meaning. It repopulates an experience with others and reminds students of the learning garnered through engagement with local residents. Similarly, students could create a collective map with others, whether as a peer group, or preferably, with local others, by mapping out where and how they moved through the city and comparing it to others' daily routes. This would be telling indeed, as it would allow both students and educators one particularly good view of exactly how wide or limited their local immersion is. Again, technology could be used to operationalize and materialize (in virtual form!) all of these explorations, and there is ample information on the web about cell phone mapping, mobile portraits, audio collages of place, and other similar possibilities.

Technology could also be used to explore the collective similarities and differences across language where significant differences exist in local vocabulary, pronunciation or common use. Students could record, map, and document linguistic differences across population groups, ethnic communities, regional affiliation, nationality, or other markers of identity. The same could also be applied to understanding variations in music across the city: for example shifts over different areas that correspond to particular musical styles, or where venues for live performance take on formal or informal settings.

In sum, technology could thus be used to help the student- flâneur enter further into the local from a constructive vantage point that enlists other senses, other urban experiences, and other residents to create larger representations that are sensory, embodied, multiple, contested and contrasting, and above all, critical. In this way, the student- flâneur that we envision utilizes technology not as a mediator but as a tool to accomplish other ways of knowing the city.

\section{Conclusions}

The flâneur of Baudelaire could be accused of not quite cutting it interculturally, as his desire to consume the city at a turtle's pace left him detached in many ways from his surroundings. Even De Certeau's wanderer may or 
may not engage, despite his critical perspective. However, both educators and students have much to learn from their ways of spectating, walking, and performing with (and within) the city. We have tried to offer a contemporary model of an active student flâneur who is critical, who is reflective, and who understands the city as co-agent in this dialogic interaction with space, place, and the people within it. Perhaps more than previous generations, our (post) modern student flâneur is well-positioned to negotiate multiple roles and to engage in a wandering that is participatory and constructive, rather than voyeuristic or merely descriptive.

Fostering flânerie in education abroad participants is not simply about slowing down and engaging students in self-reflection. And with respect to technology, it is not about representing to represent (or mapping for mapping's sake). In practice, education abroad flânerie can and should expose new ways of understanding the city in all of its "theatricality, its improvisations, its ironies" (Nuttall 2009: 37). This demands engaging students in a more localized, deliberate, and self-reflective dialogue with the city. Such a flânerie would achieve several things: first, it would make visible (and audible, etc.) the enduring differences between one place and another, reinforcing our conviction that difference still exists. Second, it would unveil a host of non-conventional urban itineraries (Mbembe and Nuttall, 2004) which unsettle tourist or other dominant portrayals of place and thus keeps students from jumping to easy, preconditioned conclusions. And finally, it would illuminate collective geographies, which contextualizes the student in something larger than "my study abroad experience."

This fits directly into any goal of fomenting concern for the world and its inhabitants. The "we" component of learning - seeing the self in context while abroad - is part-and-parcel of any environmental strategy or peace initiative that may still be possible. And this sort of "right wandering" allows students to understand the city as flexible and changing. They could, with technology in-hand or in-ear, come to recognize the uniqueness of place and the potential that the experience of the "other city" still holds within our field. We strongly encourage international educators to take advantage of the city's dynamism in order to foster more connected understandings of the local site, of a self accompanied by others, and the greater world beyond. 


\section{References}

Amin, A. and N. Thrift. (2002). Cities: Reimagining the urban. London: Polity Press.

Baudelaire, C., and J. Mayne. (1964). The painter of modern life, and other essays. London: Phaidon.

Coverly, M. (2006). Psychogeography. Harpenden: Pocket Essentials.

De Certeau, M. (1974). The Practice of Everyday Life. Translated by Steven Rendall. Berkeley and Los Angeles: University of California Press.

Debord, G. (1994). The Society of the Spectacle. Originally published 1967.

Translated by D. Nicholson-Smith. New York: Zone Books.

Cresswell, T. (2004). Place: A short introduction. Malden, MA: Blackwell.

García Canclini, N. (1995). Mexico: Cultural Globalization in a Disintegrating City. American Ethnologist, Vol. 22 (4), 743-755.

Goh, R.B.H. and B.S.A. Yeoh. (Eds.) (2003) Theorizing the Southeast Asian City as Text: Urban Landscapes, Cultural Documents, and Interpretive Experiences. New Jersey, London, Singapore, Hong Kong: World Scientific.

Hall, S. (2004). I, Mercator. In You are here: personal geographies and other maps of the imagination. Katharine Harmon (Ed). New York: Princeton Architectural Press, 15-19.

Holston, J. and A. Appadurai. (1999). Cities and citizenship. In James Holston (Ed). Cities and Citizenship. Durham, North Carolina: Duke University Press, 1-18.

Jenks, C. and T. Neves. (2000). A Walk on the Wild Side: Urban ethnography meets the flâneur. Cultural Values. 4(1), 1-17.

Knopp, L.(2007). On the relationship between queer and feminist geographies. The Professional Geographer. 59(1), 47-55.

Low, S. (1996). Spatializing culture: the social production and social construction of public space in Costa Rica. American Ethnologist, Vol. 23 (4), 861-879.

Mazlich, B. (1994). The Flâneur: from spectator to representation. In The Flâneur. Keith Tester (Ed.). London, New York: Routledge, 43-60.

Mbembe, A. and S. Nuttall (2004). Writing the world from an African metropolis. Public Culture. 16(3), 347-372.

Nuttall, S. (2009). Entanglement: Literary and cultural reflections on postapartheid. Johannesburg: Wits University Press.

Parsons, D. (2000). Streetwalking the metropolis: women, the city and modernity. Oxford: Oxford University Press. 
Perkins, C. (2007). Community mapping. The Cartographic Journal. 44(2), $127-137$.

Pile, S. (2005). Real Cities: Modernity, Space and the Phantasmagorias of City Life. London: Sage.

Pinder, D. (2005). Arts of urban exploration. Cultural Geographies. 12, $383-411$.

Pinder, D.( 2007). Cartographies unbound. Cultural Geographies. 14(3), 453-462.

Pratt, M. L. (1999) Arts of the Contact Zone. In D. Bartholome and A. Petrosky, (eds.) Ways of Reading. New York: Bedford/St. Martin's. Available at: http://www.nwe.ufl.edu/ stripp/2504/pratt.html>

Relph, E. (1976). Place and Placelessness. London: Pion.

Rink, B. (2008). Village people: Quartering De Waterkant in discourse and bricks. $\mathrm{PhD}$ thesis. University of Cape Town.

Rodríguez, K.(2009). Dentro y fuera/Inside and Out: an erotics of public space. Morelia, Mexico: Azafrán y Cinabrio Press.

Sack, R. D. (1988). The consumer's world: Place as context. Annals of the Association of American Geographers. 78(4), 642-664.

Smith, R. G. (2003). World City Actor-Networks. Progress in Human Geography. 27(1), 25-44.

Tester, K., Ed. (1994). The Flâneur. London, New York: Routledge.

Tilly, C. (2005). Identities, Boundaries, and Social Ties. Boulder, CO: Paradigm Press.

Weber, S.(2003). Streets, squares, theaters: A city on the move - Walter Benjamin's Paris. Boundary 2.30(1), 17-30.

Wood, D. (2004). Two maps of Boylan Heights. In You are here: personal geographies and other maps of the imagination. Katharine Harmon (Ed). New York: Princeton Architectural Press, 104-107. 